\title{
ANALISIS KONDISI INTERFACE ANTARA WEARING COURSE DAN BINDER COURSE DENGAN MENGGUNAKAN PROGRAM CIRCLY 5.0
}

\author{
Muhammad Hari Shofia ${ }^{1}$, Eri Susanto Haryadi ${ }^{2}$, Syaiful ${ }^{2}$ \\ ${ }^{1}$ Alumni Jurusan Teknik Sipil Fakultas Teknik Universitas Ibn Khaldun Bogor \\ ${ }^{2}$ Dosen Jurusan Teknik Sipil Fakultas Teknik Universitas Ibn Khaldun Bogor
}

\begin{abstract}
ABSTRAK
Sistem perkerasan lentur adalah konstruksi plat elastis yang berlapis-lapis dengan urutan lapisan tanah dasar (Subgrade), lapisan agregat (unbound granular), Asphalt Concrete Binder Course (AC-BC) sebagai lapisan pengikat dan Asphalt Concrete Wearing Course (AC-WC) sebagai lapis penutup. Material tack coat digunakan diantara (AC-WC) dan (AC-BC) agar tercapainya daya lekat maksimum pada interface kedua lapisan. Asumsi yang selama ini dipakai pada interface (AC-WC) dan (AC-BC) adalah kasar sempurna. Akan tetapi dalam pelaksanaannya kondisi kasar sempurna tidak dapat tercapai karena pengaruh dari suhu dan kondisi lapangan seperti debu, pasir dan genangan air. Asumsi interface kasar sempurna tidak dapat dipertahankan sehingga diperlukan penelitian tentang kondisi interface kasar parsial sesuai dengan kenyataan. Penelitian ini dimakudkan untuk mengetahui pengaruh dari penggunaan aspal tipis pada perkerasan jalan sehingga dapat memodelkan kondisi interface kasar sebagian dengan menggunakan program komputer CIRCLY 5.0. Evaluasi interface kasar sebagian dilakukan dengan memodelkan nilai modulus elastisitas pada aspal tipis struktur perkerasan lentur dengan menginput data masukan berupa traffic data, layered system, calculation detail dan running program. Digunakan variasi kondisi smooth dan rough dengan modulus elastisitas $2000 \mathrm{MPa}$, dilanjutkan dengan memodelkan lapis aspal tipis dengan Modulus Elastisitas $2 \mathrm{MPa}, 5$ $\mathrm{MPa}$, $100 \mathrm{MPa}$, dan $1600 \mathrm{MPa}$. Hasil analisa respon penurunan dan regangan menggunakan program CIRCLY didapat bahwa nilai modulus elastisitas lapisan aspal tipis sebesar $5 \mathrm{MPa}$ dapat menunjukkan kondisi interface menjadi kasar sebagian.
\end{abstract}

Kata kata kunci: Interface, Modulus elastisitas, Program CIRCLY

\begin{abstract}
Flexible pavement construction system is an elastic plate with a sequence of layered subgrade layer (subgrade), a layer of aggregate (unbound granular), Binder Course Asphalt Concrete (AC-BC) as coating binders and Asphalt Concrete Wearing Course (AC-WC) as cover layer. Materials used tack coat between ( $A C-W C)$ and $(A C-B C)$ in order to achieve maximum adhesion on the second interface layer. The assumptions that have been used on the interface (AC-WC) and (AC-BC) is the perfect rough. However, in practice the perfect rough conditions can not be achieved because of the influence of temperature and field conditions like dust, sand and water. Assumption of perfectly rough interface can not be maintained so that the necessary research about the conditions of partial rough interface in accordance with reality. Dimakudkan study was to determine the effect of the use of a thin asphalt pavement so as to model the interface rough conditions in part by using a computer program CIRCLY 5.0. Evaluation rough interface partially done by modeling the value of modulus of elasticity in thin asphalt flexible pavement structure with enter the data input of the data traffic, layered system, calculation details and running programs. Used variations of smooth and rough conditions with a modulus of elasticity of $2000 \mathrm{MPa}$, followed by modeling the thin asphalt layer modulus of elasticity of $2 \mathrm{MPa}, 5 \mathrm{MPa}, 100 \mathrm{MPa}$, and $1600 \mathrm{MPa}$. The results of the analysis using the strain response of the decline and that the value of the program CIRCLY obtained elastic modulus of thin asphalt layer 5 $\mathrm{MPa}$ can indicate the condition of the interface becomes rough part.
\end{abstract}

Keywords: Interface, Modulus of elasticity, CIRCLY Program

\section{PENDAHULUAN}

Latar Belakang

Sistem perkerasan lentur adalah konstruksi plat yang berlapis-lapis dengan urutan lapisan tanah dasar (Subgrade), lapisan agregat (unbound granular), Asphalt Concrete Binder Course $(A C-B C)$ sebagai lapisan pengikat dan Asphalt Concrete Wearing Course $(A C-W C)$ sebagai lapis penutup. Material tack coat digunakan diantara $(A C-W C)$ dan $(A C-B C)$ agar tercapainya daya lekat maksimum pada interface kedua lapisan. (Sudarsono, 1993).

Asumsi yang selama ini dipakai pada interface $(A C-W C)$ dan $(A C-B C)$ adalah kasar sempurna. Akan tetapi dalam pelaksanaannya kondisi kasar sempurna tidak dapat tercapai karena pengaruh dari suhu dan kondisi lapangan seperti debu, pasir dan genangan air. Dengan demikian asumsi interface kasar sempurna tidak dapat dipertahankan sehingga diperlukan penelitian tentang kondisi interface kasar parsial sesuai dengan kenyataan. Pada saat ini untuk menganalisa interface telah dikembangkan sebuah program komputer yang dapat memodelkan kondisi interface kedalam dua jenis yaitu kasar (rough) dan halus (smooth).

\section{Tujuan Penelitian}

Adapun tujuan penelitian ini adalah: 
1) Mengevaluasi program CIRCLY sehingga dapat menjabarkan bagaimana tata cara pengoperasian program CIRCLY.

2) Mengevaluasi respon lendutan dan regangan antara kondisi kasar (rough) dan halus (smooth).

3) Mengevaluasi respon lendutan dan regangan untuk kasar sebagian jika dimodelkan dengan lapisan aspal tipis.

\section{TINJAUAN PUSTAKA}

\section{Perkembangan Perencanaan Perkerasan} Lentur

Awal perkembangan perencanaan tebal lapis perkerasan adalah menggunakan California Bearing Ratio (CBR) untuk menentukan tebal masing-masing lapisan. Metode ini dikembangkan oleh O.J. Porter dari Departemen Jalan Raya pada tahun 1930-an dan kemudian dipakai oleh Kesatuan Teknik Tentara Amerika Serikat untuk perencanaan perkerasan landas pacu pesawat. Kurva hubungan total ketebalan perkerasan jalan terhadap tanah dasar CBR untuk beban lalu lintas yang berbeda telah dikembangkan oleh banyak negara, sebagai contoh kerajaan Inggris dan Australia, pada masa perang Dunia II. Metodenya menentukan total ketebalan dan tidak membiarkan pengurangan ketebalan akibat beda karakteristik distribusi beban dari bermacam-macam bahan atau material yang digunakan pada kontruksi perkerasan.

Percobaan dengan pengamatan fullscale pada pengujian jalan di Amerika Serikat (WASHO dan AASHO Road Test) dan setelah itu hampir bersamaan beberapa pengujian perkerasan dilakukan di Inggris yang digunakan

$$
\begin{aligned}
& \mathrm{a}=\sqrt{\frac{p}{\rho * \pi}}(1) \\
& \text { Dimana : } \quad \begin{aligned}
\mathrm{a} & =\text { radius kontak ban } \\
\mathrm{P} & =\text { Total beban } \\
\rho & =\text { tekanan ban }
\end{aligned}
\end{aligned}
$$

\section{Material Perkerasan Lentur Asphalt Concrete Wearing Course (AC-WC)}

Asphalt Concrete Wearing Course (AC$W C$ ) merupakan lapisan penutup pada perkerasan jalan. Lapisan ini memiliki nilai gradasi yang lebih halus dengan kadar aspal lebih tinggi dari lapisan lainnya. Pada penelitian ini digunakan nilai modulus elastisitas pada lapisan aspal wearing course sebesar 4000 Mpa.

\section{Asphalt Concrete Binder Coarse (AC-BC) \\ Asphalt Concrete Binider Coarse (AC- $B C)$ merupakan lapis aspal yang memiliki nilai gradasi lebih besar sehingga memiliki permukaan yang lebih kasar dari lapisan atas. Pada penelitian ini digunakan nilai modulus}

\begin{tabular}{lll} 
sebagai dasar bagi & \multicolumn{2}{c}{ pengembangan } \\
perencanaan sementara. & Metode ini \\
memperkenalkan konsep & baru pada
\end{tabular} memperkenalkan konsep baru pada
perencanaan tebal perkerasan lentur dimana pada waktu yang sama penelitian dilanjutkan pada tahap pengembangan proses analitis seperti sistem dua lapis dan sistem tiga lapis. Perkembangan program komputer untuk menghitung tegangan, regangan dan defleksi pada sistem lapis banyak baru dimulai pada tahun 1970'an. Beberapa metode perhitungan dihasilkan seperti BISAR dari Shell Oil Company dan CIRCLY. Program ini mencari tegangan, regangan dan defleksi untuk ditentukan di setiap titik pada sistem lapis banyak. Teori untuk membuat perhitungan ini telah ada sebelum perkembangan yang cepat pada teknologi komputer yang terjadi pada tahun 1970-an tetapi prosesnya sangat memerlukan tenaga dan waktu yang banyak (Manto Guitom, Tiopan Hendry, 2002).

\section{Metode Perencanaan Analitis}

Hal utama dari metode perencanaan perkerasan lentur struktural analitis mengasumsikan bahwa sebuah sistem perkerasan dan pondasinya mungkin di representasikan dengan sistem lapisan elastis yang disangga oleh masa elastis semi-infinte dan bahwa tegangan, regangan yang terjadi pada sistem yang diakibatkan oleh lalu lintas ditentukan dengan menyelesaikan persamaan elastiknya dan dibuat berdasarkan sifat-sifat elastik sistem lapisan. Berikut ini rumus untuk menentukan radius kontak ban. (Manto Guitom, Tiopan Hendry, 2002).

elastisitas pada lapisan aspal binder course sebesar $2000 \mathrm{Mpa}$.

\section{Unbound granular}

Unbound granular merupakan struktur lapisan pondasi pada perkerasan jalan. Pada penelitian ini digunakan nilai modulus elastisitas pada lapisan unbound granular sebesar 500 Mpa.

\section{Pembebanan}

Pada dasarnya gaya-gaya yang bekerja pada permukaan perkerasan dapat dibedakan menjadi 2 tipe utama. Tipe pertama adalah gaya-gaya vertikal yang disebabkan oleh beban roda dan tipe kedua adalah gaya- 
gaya horizontal yang disebabkan oleh gaya rem. (Mincad System Pty, Ltd, 2004).

Tegangan kontak antar ban dengan perkerasan adalah sama dengan kontak ban, untuk ban dengan tekanan rendah, tekanan kontak di tepi lebih besar dari pada di tengah bidang kontak. Untuk beban dengan tekanan yang tinggi, hal yang berlawanan terjadi. Pada semua pemodelan diasumsikan bahwa tekanan kontak yang terjadi adalah seragam pada bidang kontak. Bidang kontak juga diasumsikan berupa lingkaran. Jari-jari kontak tersebut ditentukan seperti pada persamaan 1.

Beban-beban pada konfigurasi sumbu tunggal dengan roda tunggal dan sumbu tunggal dengan roda ganda yang mengakibatkan jumlah kerusakan yang sama seperti sumbu standar dapat dilihat pada tabel1. (Mincad System Pty, Ltd, 2004).

Tabel 1 Beban sumbu yang menyebabkan kerusakan sama

\begin{tabular}{|c|c|c|c|c|}
\hline Konfigurasi sumbu & $\begin{array}{c}\text { Tunggal } \\
\text { Tunggal }\end{array}$ & $\begin{array}{c}\text { Tunggal } \\
\text { Ganda }\end{array}$ & $\begin{array}{c}\text { Ganda } \\
\text { Ganda }\end{array}$ & $\begin{array}{c}\text { Tiga } \\
\text { Ganda }\end{array}$ \\
\hline Load $(\mathrm{kN})$ & 53 & 80 & 135 & 181 \\
\hline
\end{tabular}

Sumber. AUSTROAD 1992

Untuk kelompok sumbu beban yang berbeda dari tabel 1 kerusakan yang terjadi dinyatakan sebagai nilai ekivalensi sumbu standar yang menghasilkan kerusakan sama.

\section{Perencanaan jalan dengan} menggunakan cara AUSTROADS dapat dibagi kedalam 3 kelompok dasar, yaitu:

1) Perencanaan lalu lintas untuk perkerasan lentur terdiri atas satu atau lebih lapis ikat.

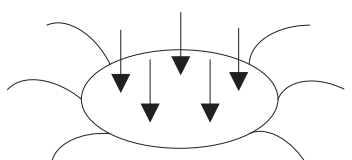

Gaya vertikal

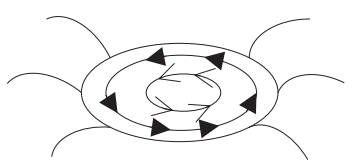

Momen akibat sumbu horizontal

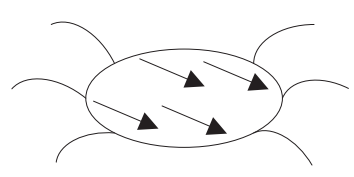

Gaya Horizontal

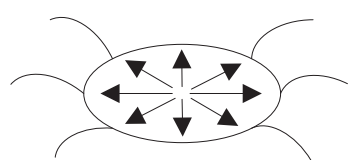

Tegangan geser radial

Gambar 1 Tipe pembebanan Sumber Austroad 1992

\section{Karakteristik Bahan}

Hingga saat ini banyak pengujian yang telah digunakan untuk mengukur karakteristik bahan perkerasan. Kebanyakan prosedur pengujian material telah distandarisasikan dan prosedurnya harus diikuti kapan saja.

\section{Isotropik dan Anisotropik}

Pada dasarnya kondisi bahan digolongkan menjadi dua golongan yaitu isotropik dan anisotropik. Yang dimaksud dengan bahan isotropik adalah apabila memiliki sifat elastik yang sama di kedua arah yaitu arah vertikal dan arah horizontal seperti bahan aspal dan semen. Sedangkan bahan anisotropik memiliki sifat atau propertis yang berbeda dalam arah sejajar dengan sumbu simetris
2) Perencanaan lalu lintas untuk perkerasan lentur yang terdiri dari lapisan unbound granular dan overlays untuk perkerasan lentur.

3) Perencanaan lalu lintas untuk perkerasan kaku (rigid).

Secara umum tipe pembebanan yang diterapkan pada area lingkaran diperlihatkan pada gambar 1 di bawah ini. (Austroads, 1992).

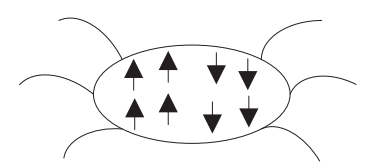

Momen akibat sumbu horizontal

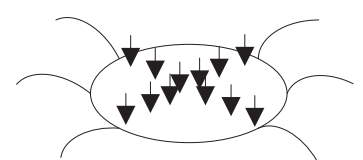

Tegangan vertikal (Rough contact) tetapi sifat elastiknya sama pada arah tegak lurus sumbu simetrisnya, seperti bahan tanah dasar dan agregat berbutir. Bahan anisotropik sumbu elastik simetri diasumsikan vertikal. Bahan isotropik terdapat pembatasan sebagai berikut:

$$
E>0 ; 1 / 2>u>-1
$$

Sedangkan untuk kondisi anisotropik pembatasannya adalah:

$$
\begin{array}{ll}
\text { Eh }=0.5 \mathrm{Ev} & (2) \\
\mathrm{u} u h=u h=u & (3) \\
f=E v /(1+u) & (4)
\end{array}
$$

Dimana: $\quad$ Eh $=$ modulus arah horizontal

Ev $=$ modulus arah vertikal

$\mathrm{u}=$ Poisson's ratio

$\mathrm{f}=$ Modulus geser bahan 


\section{Modulus Elastisitas}

Modulus elastisitas adalah rasio dari tegangan normal tarik atau tekan terhadap regangan yang timbul akibar tegangan tersebut. Secara umum persamaan untuk menentukan modulus elastisitas adalah sebagai berikut (DEP. PULP-UGM, 1972).

$$
\begin{gathered}
E=\frac{\sigma}{\varepsilon}(5) \\
\text { dimana:E = Modulus Elastisitas } \\
\sigma=\text { Tegangan } \\
\varepsilon=\text { Regangan }
\end{gathered}
$$

\section{Poisson's Ratio}

Poisson's ratio adalah nilai perbandingan antara regangan tegak lurus arah gaya dan regangan searah gaya pada material (McElvaney, James, 1988). Untuk mengetahui analisis struktur dari perkerasan dalam hal ini kekakuannya, nilai poisson's ratio harus diketahui untuk nilai tersebut. Untuk material aspal, poisso's ratio tidak tergantung pada besarnya beban tetapi terpengaruh oleh suhu. Umumnya memiliki nilai yang bervariasi antara 0.35 sampai dengan 0.50 , nilai tertinggi diakibatkan oleh suhu yang tinggi [6].

\section{Program CIRCLY}

Program CIRCLY dibuat pada sekitar tahun 1990-an dan dikembangkan oleh Melbourne Company Mincad System Pty.Ltd.. Menurut manual CIRCLY, yang disusun oleh pembuat program komputer, program ini memiliki keunggulan yang lebih daripada program terdahulu yang pernah ada. Beberapa kelebihan yang dimiliki program CIRCLY 5 adalah sebagai berikut:

1) Mampu untuk menganalisa sistem perkerasan yang sifat bahannya isotropic dan cross-anisotropic.

2) Mampu menghitung tegangan, regangan dan lendutan pada struktur perkerasan yang diakibatkan pembebanan kendaraan baik pada arah vertikal maupun horizontal.

3) Mampu menganalisa sistem perkerasan yang dibebani beban tidak terdistribusi secara merata pada bidang permukaan perkerasan.

4) Mampu menganalisa sistem perkerasan yang lebih dari tiga lapisan.

5) Mampu memodelkan kondisi interface kedalam dua jenis yaitu kasar (rough) dan halus (smooth)

Program komputer CIRCLY dikembangkan oleh Melbourne Company Mincad System Pty.Ltd. Software ini dibuat dengan mengacu pada peraturan perencanaan perkerasan Australia (AUSTROADS, 1992). Secara umum program ini pada dasarnya terbagi atas dua kelompok menu utama yaitu pertama creating, editing dan input data kedua running analysis dan plotting result .(Mincad System Pty, Ltd, 2004).

\section{Bagian Alir Program CIRCLY}

Program CIRCLY dapat digambarkan dalam bentuk diagram alir dan dijelaskan pada gambar diagram alir yang terdapat pada Gambar 2.
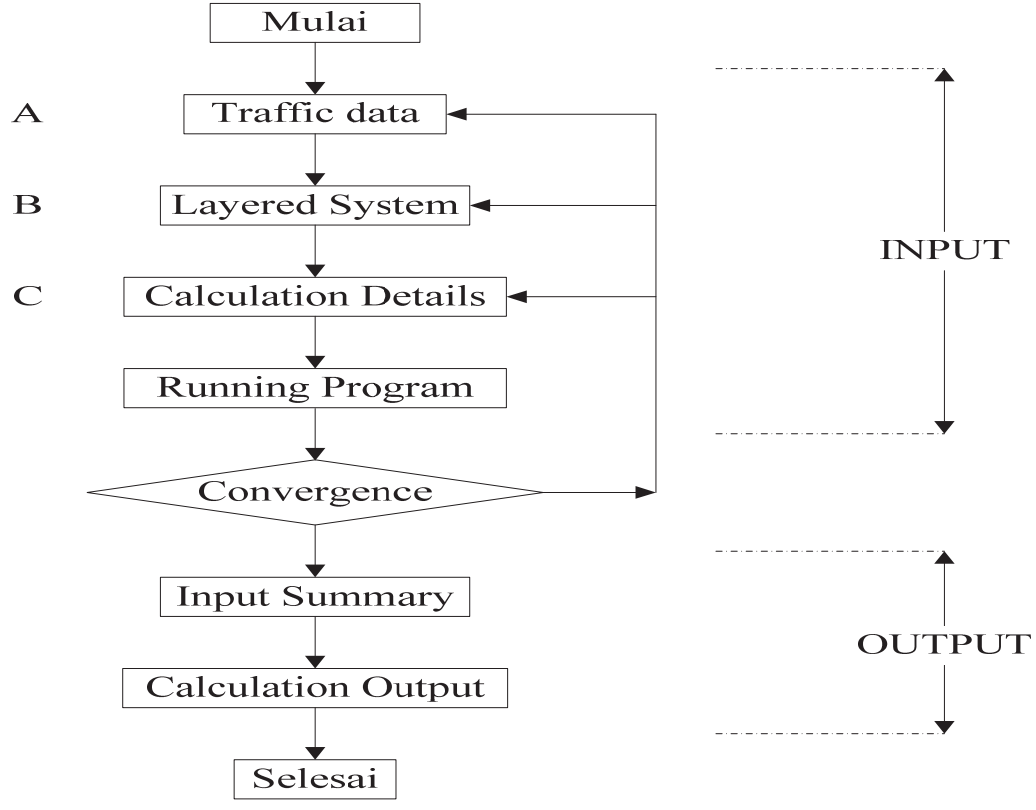

Gambar 2 Bagan Alir Program CIRCLY

\section{Proses Creating dan Editing Data}


Menu ini merupakan proses pemasukan data dan pengeditan data. Ada tiga data penting yang bisa kita masukan pada tahap ini yaitu:

1) Traffic data

2) Layered system
3) Calculation details. (Mincad System Pty, Ltd, 2004).

3. TATA KERJA

Tata Kerja dan Diagram Alir Penelitian

Tata kerja dan diagram alir dapat dilihat pada Gambar 3.

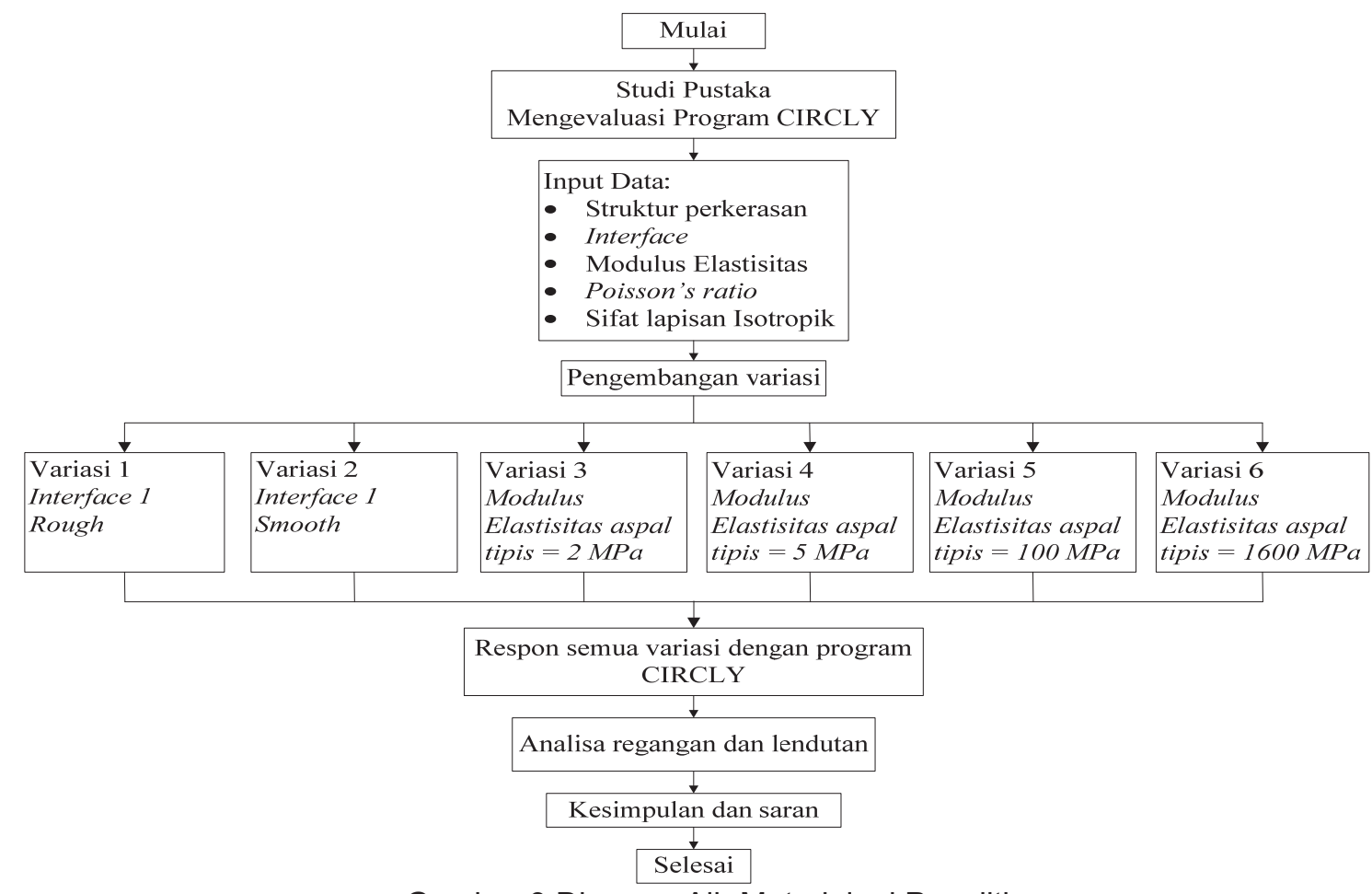

Gambar 3 Diagram Alir Metodologi Penelitian

4. HASIL DAN BAHASAN

Struktur Lapisan Perkerasan Yang Akan Diteliti
Secara umum struktur perkerasan yang akan diteliti adalah struktur perkerasan lentur yang terdiri dari beberapa lapis perkerasan sebagai berikut:

Lapis aspal tipis

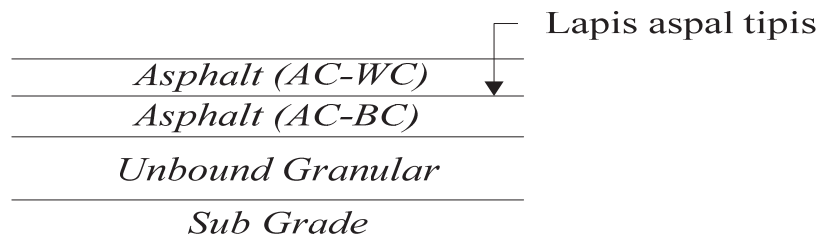

Gambar 4 Lapisan struktur perkerasan lentur

Menentukan Daerah Analisis Perkerasan Lentur

Dalam penelitian ini titik analisis ditentukan pada jarak antara $-260,37$ sampai dengan 260.37 dimana koordinat $X=0$ berada diantara ban kendaraan. Untuk lebih jelasnya dapat digambarkan sebagai berikut: 

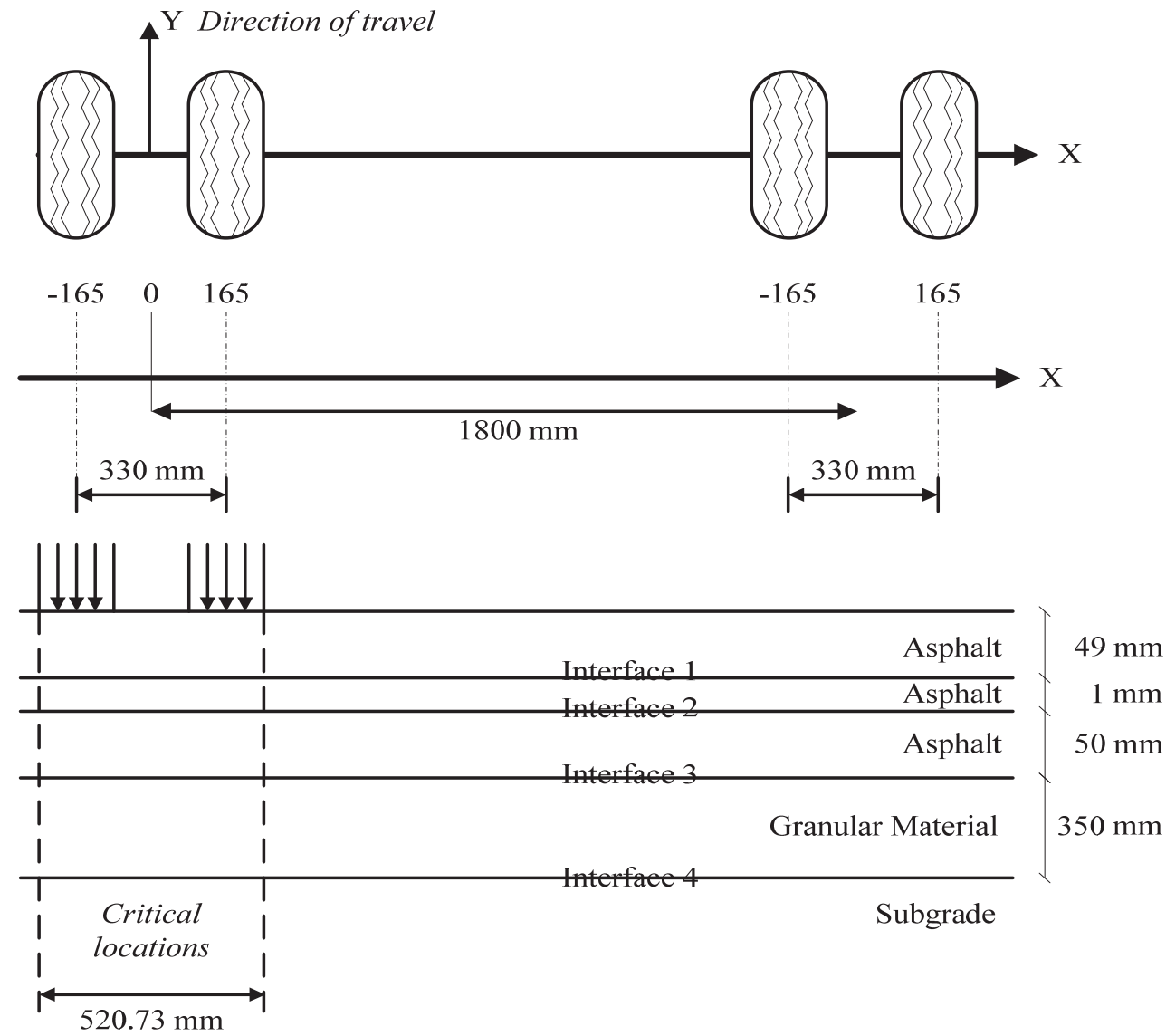

Gambar 5 Titik analisis penelitian pada program CIRCLY

\section{Menentukan Radius Kontak Ban}

Radius kontak ban ditentukan dengan menggunakan persamaan (1) sesuai dengan

$$
\begin{aligned}
& a=\sqrt{\frac{p}{P x \pi}} \\
& a=\sqrt{\frac{20}{700 x \pi}} \times 1000 \\
& a=95,37 \mathrm{~mm}
\end{aligned}
$$

Pada perhitungan ini didapat nilai radius $95,37 \mathrm{~mm}$, nilai ini yang akan dipergunakan sebagai input data untuk radius kontak ban yang diasumsikan lingkaran pada program CIRCLY.

\section{Analisis Kondisi Interface Rough dan Smooth Antara Wearing Course dan Binder Course \\ Setelah daerah analisis dan radius} kontak ban ditentukan selanjutnya diasumsikan cara yang digunakan oleh AUSTROAD. Persamaan tersebut adalah sebagai berikut: interface diantara wearing course dan binder course dengan nilai modulus elastisitas pada aspal tipis sebesar 2000 Mpa kedalam dua kondisi yaitu kasar (rough) dan halus (smooth) sesuai dengan fasilitas yang ada di program CIRCLY 5.0. Kondisi interface ini diasumsikan sebagai parameter kondisi interface sebagian. Berikut ini tabel struktur perkerasan lentur dengan mengkondisikan interface dan nilai modulus elastis pada lapisan aspal tipis sebagai berikut:

Tabel 1 Struktur perkerasan lentur dengan kondisi interface rough dan smooth

\begin{tabular}{|c|c|c|c|c|}
\hline No & Jenis lapisan & $\begin{array}{c}\text { Modulus } \\
\text { Elastisitas }\end{array}$ & Poisson's Ratio & Interface \\
\hline 1 & Asphalt & 4000 & 0.4 & Rough dan Smooth \\
2 & Asphalt & 2000 & 0.4 & Rough \\
3 & Asphalt & 2000 & 0.4 & Rough \\
4 & Granular & 500 & 0.35 & Rough \\
5 & Subgrade & 50 & 0.4 & Rough \\
\hline
\end{tabular}


Pada dasarnya program CIRCLY 5.0 Mampu menganalisis displacement, strain dan stress yang diakibatkan pembebanan kendaraan baik pada arah vertikal maupun horizontal. Dengan melihat fasilitas yang dimiliki program CIRCLY 5.0 analisa yang dilakukan terbatas pada analisis respon displacement arah vertikal pada $Z=0 \mathrm{~mm}$ (muka aspal wearing cource), normal strain arah horizontal pada $\quad Z=100 \mathrm{~mm}$ (interface antara binder course dan unbound granular) dan normal strain arah vertikal pada $Z=450 \mathrm{~mm}$ (interface antara unbound granular dan sub grade).

\section{Respon Displacement Arah Vertikal Z $=0$} mm (Muka Wearing Course)

Hasil analisis yang dikeluarkan oleh program CIRCLY 5.0 untuk respon displacement arah vertikal $Z=0 \mathrm{~mm}$ dapat dilihat pada tabel 4.2 sebagai berikut:

Tabel 2 Displacement arah vertikal $\mathrm{Z}=0 \mathrm{~mm}$ dengan kondisi interface rough dan smooth

\begin{tabular}{|c|c|c|c|}
\hline \multirow{2}{*}{ No } & \multirow{2}{*}{ Coordinate $\mathrm{X}$} & \multicolumn{2}{|c|}{ Displacement arah vertikal $\mathrm{Z}=0 \mathrm{~mm}$} \\
\hline & & Interface Rough & Interface Smooth \\
\hline 1 & -260.40 & -0.4145 & -0.4883 \\
\hline 2 & -250.40 & -0.4220 & -0.4985 \\
\hline 3 & -240.40 & -0.4281 & -0.5073 \\
\hline 4 & -230.40 & -0.4336 & -0.5153 \\
\hline 5 & -220.40 & -0.4385 & -0.5225 \\
\hline 6 & -210.40 & -0.4429 & -0.5289 \\
\hline 7 & -200.40 & -0.4467 & -0.5346 \\
\hline 8 & -190.40 & -0.4501 & -0.5393 \\
\hline 9 & -180.40 & -0.4529 & -0.5433 \\
\hline 10 & -170.40 & -0.4552 & -0.5463 \\
\hline 11 & -160.40 & -0.4570 & -0.5485 \\
\hline 12 & -150.40 & -0.4582 & -0.5499 \\
\hline 13 & -140.40 & -0.4589 & -0.5504 \\
\hline 14 & -130.40 & -0.4592 & -0.5500 \\
\hline 15 & -120.40 & -0.4589 & -0.5489 \\
\hline 16 & -110.40 & -0.4582 & -0.5470 \\
\hline 17 & -100.40 & -0.4569 & -0.5445 \\
\hline 18 & -90.36 & -0.4552 & -0.5413 \\
\hline 19 & -80.36 & -0.4528 & -0.5374 \\
\hline 20 & -70.36 & -0.4494 & -0.5323 \\
\hline 21 & -60.36 & -0.4455 & -0.5269 \\
\hline 22 & -50.36 & -0.4432 & -0.5232 \\
\hline 23 & -40.36 & -0.4415 & -0.5203 \\
\hline 24 & -30.36 & -0.4402 & -0.5180 \\
\hline 25 & -20.36 & -0.4393 & -0.5163 \\
\hline 26 & -10.36 & -0.4388 & -0.5153 \\
\hline 27 & -0.37 & -0.4386 & -0.5150 \\
\hline 28 & 9.64 & -0.4387 & -0.5153 \\
\hline 29 & 19.64 & -0.4392 & -0.5162 \\
\hline 30 & 29.64 & -0.4401 & -0.5178 \\
\hline 31 & 39.64 & -0.4414 & -0.5201 \\
\hline 32 & 49.64 & -0.4431 & -0.5230 \\
\hline 33 & 59.64 & -0.4453 & -0.5266 \\
\hline
\end{tabular}




\begin{tabular}{|l|l|l|l|}
34 & 69.64 & -0.4489 & -0.5318 \\
\hline 35 & 79.64 & -0.4526 & -0.5370 \\
\hline 36 & 89.64 & -0.4550 & -0.5410 \\
\hline 37 & 99.64 & -0.4568 & -0.5443 \\
\hline 38 & 109.60 & -0.4581 & -0.5469 \\
\hline 39 & 119.60 & -0.4589 & -0.5488 \\
\hline 40 & 129.60 & -0.4592 & -0.5500 \\
\hline 41 & 139.60 & -0.4590 & -0.5504 \\
\hline 42 & 149.60 & -0.4583 & -0.5499 \\
\hline 43 & 159.60 & -0.4571 & -0.5487 \\
\hline 44 & 169.60 & -0.4553 & -0.5465 \\
\hline 45 & 179.60 & -0.4531 & -0.5435 \\
\hline 46 & 189.60 & -0.4503 & -0.5397 \\
\hline 47 & 199.60 & -0.4470 & -0.5349 \\
\hline 48 & 209.60 & -0.4432 & -0.5294 \\
\hline 49 & 219.60 & -0.4388 & -0.5230 \\
\hline 50 & 229.60 & -0.4340 & -0.5158 \\
\hline 51 & 239.60 & -0.4285 & -0.5079 \\
\hline 52 & 249.60 & -0.4225 & -0.4992 \\
\hline 53 & 259.60 & -0.4152 & -0.4892 \\
\hline
\end{tabular}

Dari tabel 2 dapat dilihat nilai displacement arah vertikal maksimum pada kondisi interface rough yaitu sebesar $\mathrm{Y}=$ $0.4592 \mathrm{~mm}$ yang berada pada koordinat $X=$ $130,40 \mathrm{~mm}$ dan nilai minimum yaitu sebesar $Y$ $=-0,4386 \mathrm{~mm}$ yang berada di poros antara ban kendaraan sehingga dapat diketahui rentang displacement pada kondisi interface rough adalah 0,0206 mm, akan tetapi untuk kondisi interface smooth memiliki nilai maksimum sebesar $Y=-0,5504 \mathrm{~mm}$ yang berada pada koordinat $X=140,40 \mathrm{~mm}$ dan nilai minimum sebesar $Y=-0,5150 \mathrm{~mm}$ yang berada di poros antara ban kendaraan sehingga dapat diketahui rentang displacement pada kondisi interface smooth adalah sebesar $0,0354 \mathrm{~mm}$.

Untuk lebih jelasnya perbedaan displacement arah vertikal $\mathbf{Z}=0 \mathrm{~mm}$ pada kondisi interface rough dan smooth dapat dilihat pada gambar 3 dibawah ini: 
Ban kendaraan
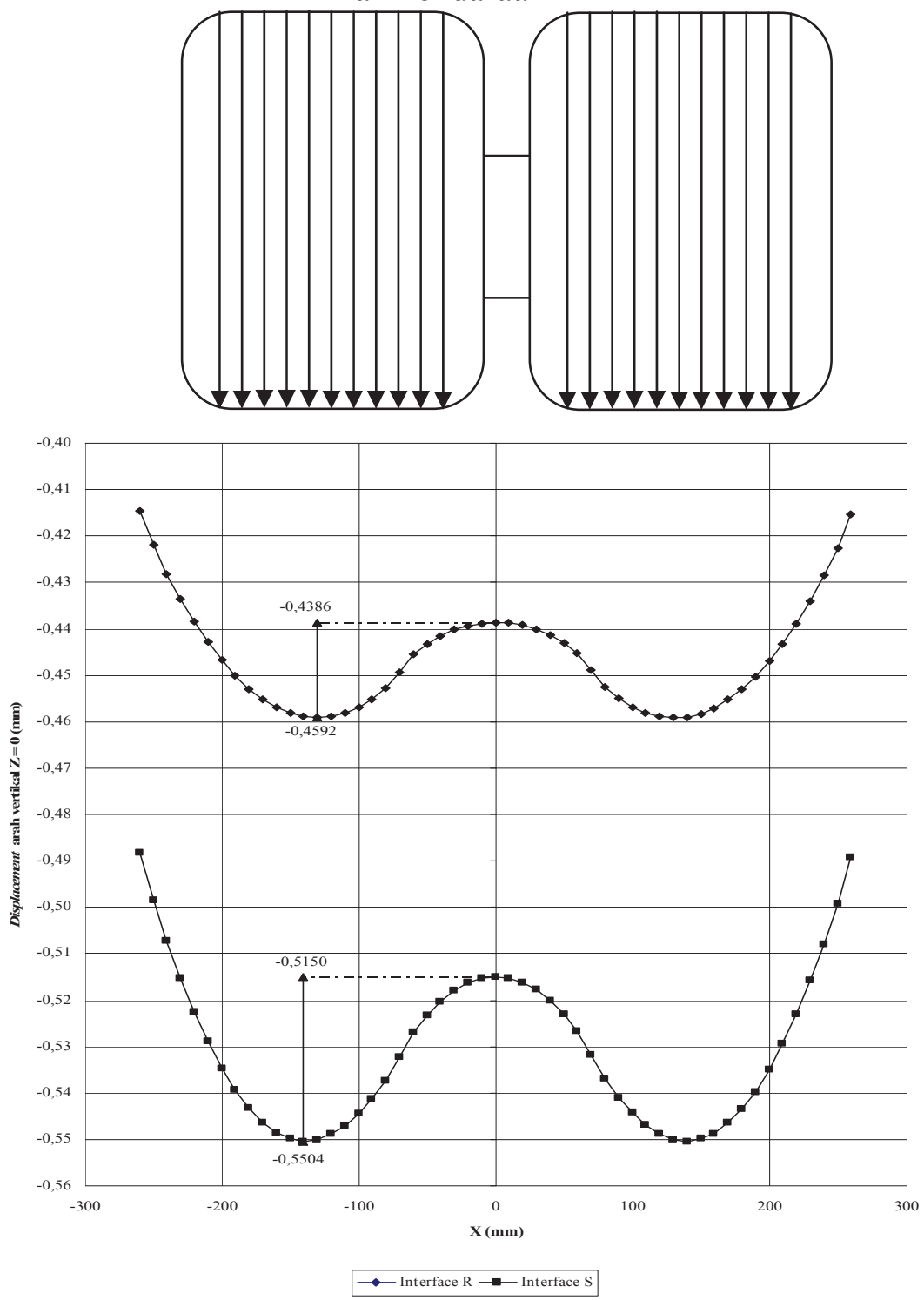

Gambar 3 Respon displacement arah vertikal Z $=0$ mm (muka wearing course)

Respon Regangan Normal Arah Horizontal Z $=100 \mathrm{~mm}$ (Interface Antara Binder Course dan Unbound Granular)
Hasil analisis yang dikeluarkan oleh program CIRCLY 5.0 untuk respon regangan normal arah horizontal $Z=100 \mathrm{~mm}$ dapat dilihat pada tabel 3 sebagai berikut:

Tabel 3 Regangan normal arah horizontal $Z=100 \mathrm{~mm}$ dengan kondisi interface rough dan smooth

\begin{tabular}{|r|c|c|c|}
\hline \multirow{2}{*}{ No } & \multirow{2}{*}{ Coordinate X } & \multicolumn{2}{|c|}{ Regangan normal arah horizontal Z $=100 \mathrm{~mm}$} \\
\cline { 3 - 4 } & & Interface Rough & Interface Smooth \\
\hline \hline 1 & $-260,40$ & $-0,0001325$ & $-0,00006988$ \\
\hline 2 & $-250,40$ & $-0,0001411$ & $-0,00007915$ \\
\hline 3 & $-240,40$ & $-0,0001493$ & $-0,00008780$ \\
\hline 4 & $-230,40$ & $-0,0001569$ & $-0,00009562$ \\
\hline 5 & $-220,40$ & $-0,0001636$ & $-0,00010240$ \\
\hline 6 & $-210,40$ & $-0,0001696$ & $-0,00010820$ \\
\hline 7 & $-200,40$ & $-0,0001746$ & $-0,00011280$ \\
\hline 8 & $-190,40$ & $-0,0001788$ & $-0,00011630$ \\
\hline 9 & $-180,40$ & $-0,0001820$ & $-0,00011870$ \\
\hline 10 & $-170,40$ & $-0,0001843$ & $-0,00012020$ \\
\hline
\end{tabular}




\begin{tabular}{|c|c|c|c|}
\hline 11 & $-160,40$ & $-0,0001857$ & $-0,00012070$ \\
\hline 12 & $-150,40$ & $-0,0001863$ & $-0,00012020$ \\
\hline 13 & $-140,40$ & $-0,0001860$ & $-0,00011870$ \\
\hline 14 & $-130,40$ & $-0,0001848$ & $-0,00011630$ \\
\hline 15 & $-120,40$ & $-0,0001828$ & $-0,00011290$ \\
\hline 16 & $-110,40$ & $-0,0001800$ & $-0,00010850$ \\
\hline 17 & $-100,40$ & $-0,0001766$ & $-0,00010320$ \\
\hline 18 & $-90,36$ & $-0,0001726$ & $-0,00009711$ \\
\hline 19 & $-80,36$ & $-0,0001681$ & $-0,00009043$ \\
\hline 20 & $-70,36$ & $-0,0001634$ & $-0,00008344$ \\
\hline 21 & $-60,36$ & $-0,0001587$ & $-0,00007643$ \\
\hline 22 & $-50,36$ & $-0,0001543$ & $-0,00006975$ \\
\hline 23 & $-40,36$ & $-0,0001502$ & $-0,00006373$ \\
\hline 24 & $-30,36$ & $-0,0001469$ & $-0,00005868$ \\
\hline 25 & $-20,36$ & $-0,0001443$ & $-0,00005485$ \\
\hline 26 & $-10,36$ & $-0,0001427$ & $-0,00005245$ \\
\hline 27 & $-0,37$ & $-0,0001421$ & $-0,00005159$ \\
\hline 28 & 9,64 & $-0,0001426$ & $-0,00005233$ \\
\hline 29 & 19,64 & $-0,0001442$ & $-0,00005462$ \\
\hline 30 & 29,64 & $-0,0001466$ & $-0,00005835$ \\
\hline 31 & 39,64 & $-0,0001500$ & $-0,00006333$ \\
\hline 32 & 49,64 & $-0,0001540$ & $-0,00006929$ \\
\hline 33 & 59,64 & $-0,0001584$ & $-0,00007593$ \\
\hline 34 & 69,64 & $-0,0001631$ & $-0,00008292$ \\
\hline 35 & 79,64 & $-0,0001678$ & $-0,00008993$ \\
\hline 36 & 89,64 & $-0,0001722$ & $-0,00009664$ \\
\hline 37 & 99,64 & $-0,0001763$ & $-0,00010280$ \\
\hline 38 & 109,60 & $-0,0001798$ & $-0,00010820$ \\
\hline 39 & 119,60 & $-0,0001826$ & $-0,00011260$ \\
\hline 40 & 129,60 & $-0,0001847$ & $-0,00011610$ \\
\hline 41 & 139,60 & $-0,0001859$ & $-0,00011860$ \\
\hline 42 & 149,60 & $-0,0001863$ & $-0,00012010$ \\
\hline 43 & 159,60 & $-0,0001858$ & $-0,00012060$ \\
\hline 44 & 169,60 & $-0,0001844$ & $-0,00012020$ \\
\hline 45 & 179,60 & $-0,0001822$ & $-0,00011890$ \\
\hline 46 & 189,60 & $-0,0001790$ & $-0,00011650$ \\
\hline 47 & 199,60 & $-0,0001750$ & $-0,00011310$ \\
\hline 48 & 209,60 & $-0,0001700$ & $-0,00010850$ \\
\hline 49 & 219,60 & $-0,0001641$ & $-0,00010290$ \\
\hline 50 & 229,60 & $-0,0001574$ & $-0,00009615$ \\
\hline 51 & 239,60 & $-0,0001499$ & $-0,00008840$ \\
\hline 52 & 249,60 & $-0,0001418$ & $-0,00007980$ \\
\hline 53 & 259,60 & $-0,0001331$ & $-0,00007057$ \\
\hline
\end{tabular}


Dari tabel 3 dapat dilihat nilai regangan normal arah horizontal maksimum pada kondisi interface rough yaitu sebesar $Y=-0.0001863$ yang berada pada koordinat $X=-150,40 \mathrm{~mm}$ dan nilai minimum yaitu sebesar $\quad Y=$ 0,0001421 yang berada di poros antara ban kendaraan sehingga dapat diketahui rentang regangan normal pada kondisi interface rough adalah 0,0000442, akan tetapi untuk kondisi interface smooth memiliki nilai maksimum sebesar $Y=-0,00012070$ yang berada pada koordinat $X=160,40 \mathrm{~mm}$ dan nilai minimum sebesar $Y=-0,00005159$ yang berada di poros antara ban kendaraan sehingga dapat diketahui rentang regangan normal pada kondisi interface smooth adalah 0,00006911.

Untuk lebih jelasnya perbedaan regangan normal arah horizontal $Z=100 \mathrm{~mm}$ pada kondisi interface rough dan smooth dapat dilihat pada gambar 4 dibawah ini: Ban kendaraan

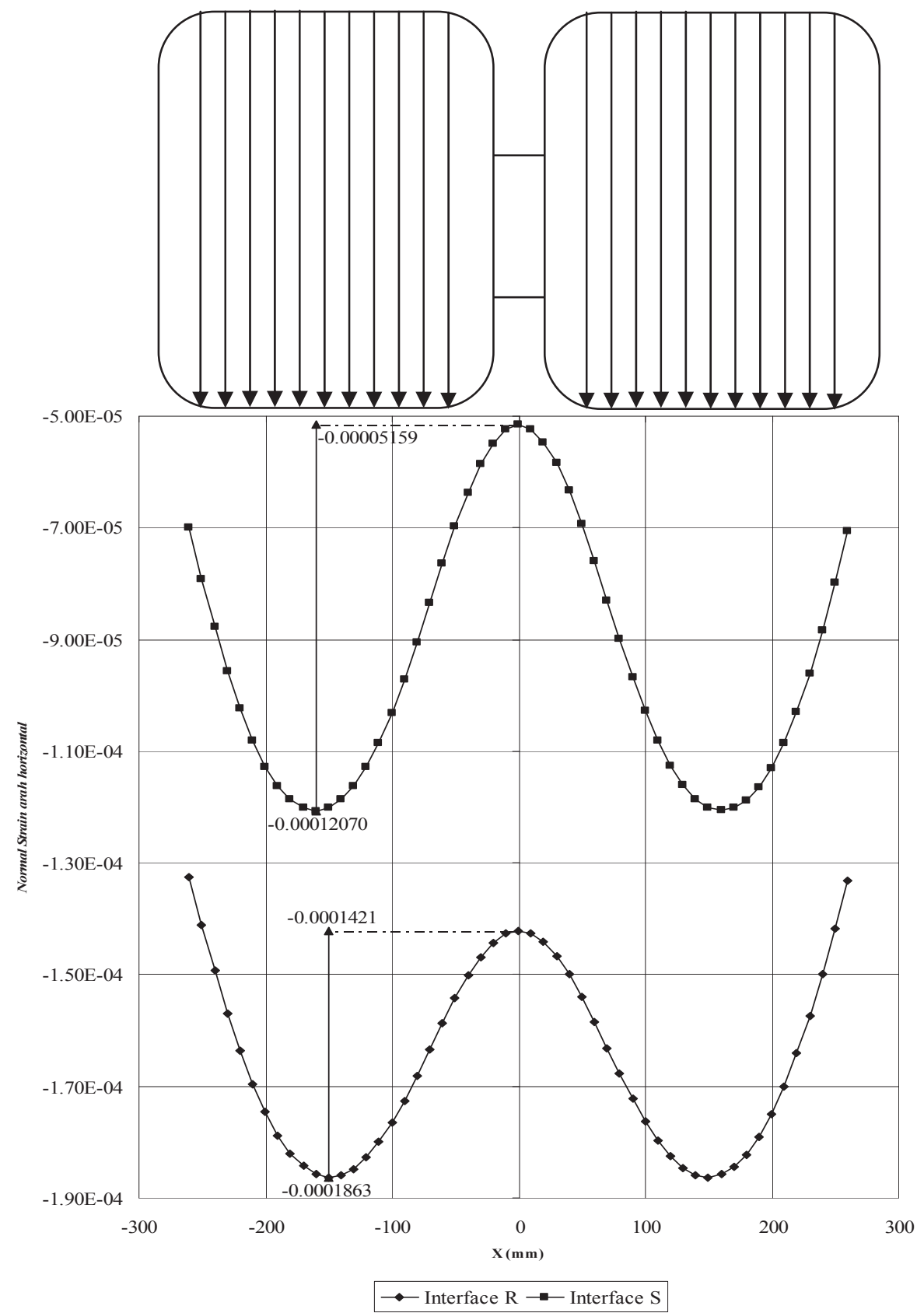

Gambar 4 Respon regangan normal arah horizontal Z = $100 \mathrm{~mm}$ (interface antara binder course dan unbound granular)

Respon Regangan Normal Arah Vertikal Z = $450 \mathrm{~mm}$ (Interface Antara Unbound Granular dan Sub Grade)
Hasil analisis yang dikeluarkan oleh program CIRCLY 5.0 untuk respon regangan normal arah vertikal $Z=450 \mathrm{~mm}$ dapat dilihat pada tabel 4 sebagai berikut: 
Tabel 4 Regangan normal arah vertikal $Z=450 \mathrm{~mm}$ dengan kondisi interface rough dan smooth

\begin{tabular}{|c|c|c|c|}
\hline \multirow{2}{*}{ No } & \multirow{2}{*}{ Coordinate X } & \multicolumn{2}{|c|}{ Regangan normal arah vertikal $Z=450 \mathrm{~mm}$} \\
\hline & & Interface Rough & Interface Smooth \\
\hline 1 & $-260,40$ & 0,0003082 & 0,0003935 \\
\hline 2 & $-250,40$ & 0,0003137 & 0,0004019 \\
\hline 3 & $-240,40$ & 0,0003192 & 0,0004101 \\
\hline 4 & $-230,40$ & 0,0003244 & 0,0004179 \\
\hline 5 & $-220,40$ & 0,0003294 & 0,0004254 \\
\hline 6 & $-210,40$ & 0,0003343 & 0,0004326 \\
\hline 7 & $-200,40$ & 0,0003390 & 0,0004394 \\
\hline 8 & $-190,40$ & 0,0003434 & 0,0004459 \\
\hline 9 & $-180,40$ & 0,0003476 & 0,0004520 \\
\hline 10 & $-170,40$ & 0,0003516 & 0,0004576 \\
\hline 11 & $-160,40$ & 0,0003553 & 0,0004629 \\
\hline 12 & $-150,40$ & 0,0003588 & 0,0004677 \\
\hline 13 & $-140,40$ & 0,0003620 & 0,0004722 \\
\hline 14 & $-130,40$ & 0,0003650 & 0,0004762 \\
\hline 15 & $-120,40$ & 0,0003678 & 0,0004799 \\
\hline 16 & $-110,40$ & 0,0003703 & 0,0004832 \\
\hline 17 & $-100,40$ & 0,0003725 & 0,0004861 \\
\hline 18 & $-90,36$ & 0,0003746 & 0,0004887 \\
\hline 19 & $-80,36$ & 0,0003764 & 0,0004910 \\
\hline 20 & $-70,36$ & 0,0003780 & 0,0004929 \\
\hline 21 & $-60,36$ & 0,0003793 & 0,0004946 \\
\hline 22 & $-50,36$ & 0,0003805 & 0,0004960 \\
\hline 23 & $-40,36$ & 0,0003814 & 0,0004971 \\
\hline 24 & $-30,36$ & 0,0003821 & 0,0004979 \\
\hline 25 & $-20,36$ & 0,0003826 & 0,0004985 \\
\hline 26 & $-10,36$ & 0,0003829 & 0,0004989 \\
\hline 27 & $-0,37$ & 0,0003831 & 0,0004990 \\
\hline 28 & 9,64 & 0,0003830 & 0,0004989 \\
\hline 29 & 19,64 & 0,0003827 & 0,0004985 \\
\hline 30 & 29,64 & 0,0003822 & 0,0004980 \\
\hline 31 & 39,64 & 0,0003815 & 0,0004971 \\
\hline 32 & 49,64 & 0,0003805 & 0,0004960 \\
\hline 33 & 59,64 & 0,0003794 & 0,0004947 \\
\hline 34 & 69,64 & 0,0003781 & 0,0004931 \\
\hline 35 & 79,64 & 0,0003765 & 0,0004912 \\
\hline 36 & 89,64 & 0,0003747 & 0,0004889 \\
\hline 37 & 99,64 & 0,0003727 & 0,0004863 \\
\hline 38 & 109,60 & 0,0003705 & 0,0004834 \\
\hline 39 & 119,60 & 0,0003680 & 0,0004802 \\
\hline 40 & 129,60 & 0,0003652 & 0,0004765 \\
\hline 41 & 139,60 & 0,0003622 & 0,0004725 \\
\hline
\end{tabular}




\begin{tabular}{|l|l|l|l|}
42 & 149,60 & 0,0003590 & 0,0004681 \\
\hline 43 & 159,60 & 0,0003555 & 0,0004632 \\
\hline 44 & 169,60 & 0,0003518 & 0,0004580 \\
\hline 45 & 179,60 & 0,0003479 & 0,0004524 \\
\hline 46 & 189,60 & 0,0003437 & 0,0004463 \\
\hline 47 & 199,60 & 0,0003393 & 0,0004399 \\
\hline 48 & 209,60 & 0,0003347 & 0,0004331 \\
\hline 49 & 219,60 & 0,0003298 & 0,0004260 \\
\hline 50 & 229,60 & 0,0003248 & 0,0004185 \\
\hline 51 & 239,60 & 0,0003195 & 0,0004107 \\
\hline 52 & 249,60 & 0,0003141 & 0,0004025 \\
\hline 53 & 259,60 & 0,0003086 & 0,0003942 \\
\hline
\end{tabular}

Dari tabel 4 dapat dilihat nilai regangan normal arah vertikal yang maksimum pada kondisi interface rough yaitu sebesar $Y=$ 0,0003831 yang berada di poros antara ban kendaraan dan nilai minimum yaitu sebesar $Y=$ 0,0003082 yang berada di tepi luar ban kendaraan sehingga dapat diketahui rentang regangan normal pada kondisi interface rough adalah 0,0000749, akan tetapi untuk kondisi interface smooth memiliki nilai maksimum sebesar $Y=0,0004990$ yang berada di poros antara ban kendaraan dan nilai minimum sebesar $Y=0,0003935$ yang berada di tepi luar ban kendaraan sehingga diketahui panjang antara nilai minimum sampai dengan nilai maksimum adalah sebesar 0,0001055.

\section{Analisis Pemodelan Modulus Elastisitas Pada Lapisan Aspal Tipis \\ Setelah memodelkan kondisi interface} kedalam dua jenis yaitu kasar (rough) dan halus (smooth), selanjutnya memodelkan nilai modulus elastisitas pada lapisan aspal tipis untuk mengetahui kondisi interface sebagian. Adapun nilai pemodelan modulus elastisitas pada aspal tipis adalah sebagai berikut:

Tabel 5 Nilai pemodelan modulus elastisitas

\begin{tabular}{|c|c|}
\hline Variasi & Modulus Elastisitas (MPa) \\
\hline 1 & 2 \\
2 & 5 \\
3 & 100 \\
4 & 1600 \\
\hline
\end{tabular}

Tabel 6 Nilai maksimum dan minimum pada respon displacement arah vertikal Z $=0$

\begin{tabular}{|c|c|c|c|c|c|}
\hline Variasi & $\begin{array}{c}\text { Kondisi } \\
\text { Interface }\end{array}$ & $\begin{array}{c}\text { Modulus Elastisitas } \\
(\mathrm{MPa})\end{array}$ & $\begin{array}{c}\text { Maksimum } \\
(\mathrm{mm})\end{array}$ & $\begin{array}{c}\text { Minimum } \\
(\mathrm{mm})\end{array}$ & $\begin{array}{c}\text { Rentang } \\
(\mathrm{mm})\end{array}$ \\
\hline 1 & Rough & 2000 & $-0,4592$ & $-0,4386$ & 0,0206 \\
2 & Rough & 2 & $-0,5798$ & $-0,5125$ & 0,0670 \\
3 & Rough & 5 & $-0,5267$ & $-0,4736$ & 0,0531 \\
4 & Rough & 100 & $-0,4659$ & $-0,4404$ & 0,0255 \\
5 & Rough & 1600 & $-0,4590$ & $-0,4386$ & 0,0201 \\
6 & Smooth & 2000 & $-0,5504$ & $-0,5150$ & 0,0354 \\
\hline
\end{tabular}

Dari tabel 6 dapat diketahui respon displacement arah vertikal untuk kondisi interface sebagian berada pada nilai modulus elastisitas $5 \mathrm{Mpa}$. Nilai maksimum yang didapat pada Modulus elastisitas 5 Mpa adalah $-0,5267$ $\mathrm{mm}$ dan nilai minimum $-0,4736 \mathrm{~mm}$ sehingga rentang displacement arah vertikal yang terjadi adalah $0,0531 \mathrm{~mm}$. Penggunaan nilai Modulus elastisitas yang lebih kecil (2 Mpa) memperlihatkan kondisi interface yang mendekati halus dan memiliki rentang yang sangat besar, sedangkan penggunaan nilai modulus elastisitas yang lebih besar (1600
Mpa) memperlihatkan kondisi interface yang mendekati kasar dan memiliki rentang yang kecil.

Respon Regangan Normal Arah Horizontal pada $Z=100$ Setelah Memodelkan Nilai Modulus Elastisitas Pada Lapisan Aspal Tipis

Nilai pada respon regangan normal arah horizontal $Z=100$ setelah memodelkan nilai modulus elastisitas pada lapisan aspal tipis dapat dilihat pada tabel 8 dan gambar 7 di bawah ini: 
Tabel 7 Nilai maksimum dan minimum pada respon regangan normal arah horizontal $Z=100$

\begin{tabular}{|c|c|c|c|c|c|}
\hline Variasi & $\begin{array}{c}\text { Kondisi } \\
\text { Interface }\end{array}$ & $\begin{array}{c}\text { Modulus } \\
\text { Elastisitas } \\
(\mathrm{MPa})\end{array}$ & Maksimum & Minimum & Rentang \\
\hline 1 & Rough & 2000 & $-0,0001863$ & $-0,00014213$ & 0,00004417 \\
2 & Rough & 2 & $-0,00009697$ & $-0,00007338$ & 0,00002359 \\
3 & Rough & 5 & $-0,0001346$ & $-0,00009721$ & 0,00003739 \\
4 & Rough & 100 & $-0,0001848$ & $-0,0001374$ & 0,00004740 \\
5 & Rough & 1600 & $-0,0001863$ & $-0,00014209$ & 0,00004421 \\
6 & Smooth & 2000 & $-0,0001207$ & $-0,00005159$ & 0,00006911 \\
\hline
\end{tabular}

Dari tabel 7 dapat diketahui respon regangan normal arah horizontal untuk kondisi interface sebagian berada pada nilai modulus elastisitas $5 \mathrm{Mpa}$. Nilai maksimum yang didapat pada Modulus elastisitas $5 \mathrm{Mpa}$ adalah 0,0001346 dan nilai minimum $-0,00009721$ sehingga rentang regangan normal arah horizontal yang terjadi adalah 0,00003739 .
Penggunaan nilai Modulus elastisitas yang lebih kecil (2 Mpa) memperlihatkan kondisi interface yang mendekati halus dan memiliki rentang yang kecil, sedangkan penggunaan nilai modulus yang lebih besar (1600 Mpa) memperlihatkan kondisi interface yang mendekati kasar dan memiliki rentang yang besar.

Tabel 8 Nilai maksimum dan minimum pada respon regangan normal arah vertikal $Z=450$

\begin{tabular}{|c|c|c|c|c|c|}
\hline Variasi & $\begin{array}{c}\text { Kondisi } \\
\text { Interface }\end{array}$ & $\begin{array}{c}\text { Modulus } \\
\text { Elastisitas } \\
(\mathrm{MPa})\end{array}$ & Maksimum & Minimum & Rentang \\
\hline 1 & Rough & 2000 & 0,00038305 & 0,00030817 & 0,00007488 \\
2 & Rough & 2 & 0,0004520 & 0,0003556 & 0,0000964 \\
3 & Rough & 5 & 0,0004325 & 0,0003423 & 0,0000902 \\
4 & Rough & 100 & 0,0003882 & 0,0003120 & 0,0000762 \\
5 & Rough & 1600 & 0,00038313 & 0,00030823 & 0,0000749 \\
6 & Smooth & 2000 & 0,0004990 & 0,0003935 & 0,0001055 \\
\hline
\end{tabular}

Dari tabel 8 dapat diketahui respon regangan normal arah vertikal untuk kondisi interface sebagian berada pada nilai modulus elastisitas $5 \mathrm{Mpa}$. Nilai maksimum yang didapat pada Modulus elastisitas $5 \mathrm{Mpa}$ adalah 0,0004325 dan nilai minimumnya 0,0003423 sehingga rentang penurunan yang terjadi adalah 0,0000902. Penggunaan nilai Modulus

\section{KESIMPULAN DAN SARAN}

Ditinjau dari hasil analisis perkerasan jalan yang dilakukan dengan menggunakan program komputer CIRCLY untuk sistem lima lapisan dari pemodelan mutu bahan, diperoleh beberapa kesimpulan sebagai berikut:

1) Program CIRCLY dapat dipergunakan untuk mengevaluasi kondisi interface kasar sebagian dengan memodelkan lapis aspal tipis pada struktur perkerasan lentur.

2) Respon displacement dan regangan normal arah vertikal memperlihatkan apabila nilai modulus elastisitas semakin mengecil (2 $\mathrm{MPa}$ ) maka rentang yang terjadi akan semakin besar dengan arah pembebanan yang berlawanan sedangkan respon regangan normal arah horizontal memperlihatkan apabila nilai modulus elastisitas semakin mengecil (2 MPa) maka rentang yang terjadi akan semakin kecil dan beban cenderung merata. elastisitas yang lebih kecil (2 Mpa) memperlihatkan kondisi interface yang mendekati halus dan memiliki rentang yang besar, sedangkan penggunaan nilai modulus yang lebih besar (1600 Mpa) memperlihatkan kondisi interface yang mendekati kasar dan memiliki rentang yang kecil.

3) Displacement dan regangan normal pada kondisi interface Rough memiliki rentang nilai yang lebih kecil dibandingkan dengan kondisi interface Smooth, yang artinya struktur dari kedua lapisan saling mengikat sehingga beban yang diterima dapat dipikul oleh kedua lapisan tersebut.

4) Dari hasil analisa respon displacement dan regangan menggunakan program CIRCLY didapat bahwa penggunaan aspal tipis dengan nilai modulus elastisitas $2 \mathrm{MPa}$ sampai dengan $1600 \mathrm{MPa}$ dapat memperlihatkan kondisi interface kasar sebagian.

\section{Saran}

Ditinjau dari hasil analisis dengan menggunakan program CIRCLY maka diperoleh beberapa saran sebagai berikut: 
1) Perlu diadakan suatu studi lanjutan dengan menggunakan program CIRCLY untuk menganalisis struktur perkerasan lentur dengan arah pembeban horizontal.

2) Perlu diadakan penelitian yang sesungguhnya (studi kasus) sebagai input data yang akan dievaluasi oleh program CIRCLY.

3) Diperlukan pengembangan program CIRCLY untuk memodelkan kondisi interface kedalam tiga jenis yaitu kasar, halus dan kondisi interface yang berada di antaranya.

\section{DAFTAR PUSTAKA}

Sudarsono, DU., Konstruksi Jalan Raya, Badan Penerbit Pekerjaan Umum, Jakarta, 1993.

Mincad System Pty, Ltd., CIRCLY User Manual, Australia, 2004.
Manto Guitom, Tiopan Hendry., Analisis Perkerasan Lentur Untuk Kondisi Isotropik dan Anisotropik Menggunakan Program CIRCLY 4, Tesis Bidang Khusus Rekayasa Transportasi Program Pascasarjana Institut Teknologi Bandung, Bandung, 2002.

McElvaney, James., Layered Elastic Analysis and the Structural Design of Flexible Pavement, Seminar on Road Design and Evaluation Department of Civil and Structural Engineering University of Hong Kong, Hongkong, 1988.

Panitia DEP. PULP-UGM., Istilah Teknik Sipil Inggris - Indonesia, Badan Penerbit Pekerjaan Umum, Jakarta, 1972.

Austroads., Pavement Design A Guide to the Structural Design of Road Pavements, Austroads, Sydney, 1992. 